\title{
Air quality in cities of the extreme south of Brazil
}

\author{
Silva Júnior, F.M.R. ${ }^{1,2^{*}}$, Honscha, L.C. ${ }^{1,2}$, Brum, R.L. ${ }^{1,2}$, Ramires, P.F. ${ }^{1,2}$, TAVella, R.A. ${ }^{1,2}$, \\ Fernandes, C.L.F. ${ }^{1,2}$, Penteado, J.O. ${ }^{1,2}$, Bonifácio, A.S. ${ }^{1}$, Volcão, L.M. ${ }^{1,2}$, \\ SAntos, M. ${ }^{1,2} \&$ COROnAs, M.V. ${ }^{3}$ \\ ${ }^{1}$ Instituto de Ciências Biológicas (ICB), Universidade Federal do Rio Grande - FURG \\ ${ }^{2}$ Programa de Pós-Graduação em Ciências da Saúde, Faculdade de Medicina (FAMED), Universidade Federal do Rio Grande - FURG \\ ${ }^{3}$ Universidade Federal de Santa Maria
}

Received July 12, 2020; Accept September 03, 2020

\begin{abstract}
The region comprised of cities located in the extreme south of Brazil has numerous potential sources of pollution, such as industries, mining and agricultural activities. Despite this, they do not have detailed scientific information regarding air quality. The present study aimed to evaluate air quality in nine municipalities in the extreme south of Brazil, based on the monitoring of six pollutants $\left(\mathrm{O}_{3}, \mathrm{NO}_{2}, \mathrm{SO}_{2}, \mathrm{PM}_{2.5}, \mathrm{PM}_{10}\right.$ and $\left.\mathrm{CO}\right)$ present in Brazilian environmental legislation and the relationship of these pollutants with meteorological parameters. Information on air pollutants and meteorological parameters was collected from satellite data from the European Centre for Medium-Range Weather Forecasts "Copernicus Atmospheric Monitoring Service", extracted using The Wealther Channel (IBM, USA) during the period ranged from April 25, 2020 to July 4, 2020 in Rio Grande, Pelotas, Bagé, Candiota, Hulha Negra, Pedras Altas, Aceguá and Herval. The concentration of pollutants was below Brazilian limits, with the exception of a single episode in the municipality of Rio Grande. Temperature was the meteorological parameter most correlated with air pollutants, except for $\mathrm{SO}_{2}$, but in general, all pollutants correlated (positive or negative) with at least one atmospheric parameter. Finally, the composition of air pollutants in each municipality seems to be related to its local economic activity. We encourage the continuity of studies in the region aiming at a complete temporal analysis that encompasses all seasons.
\end{abstract}

Keywords: Correlation analysis, Criteria air pollutants, Meteorological parameters, Rio Grande do Sul, Urban air quality.

\section{INTRODUCTION}

Since 2013, the World Health Organization (WHO) has classified external air pollution as a carcinogen for humans and recent studies have shown that living and breathing air in large urban centers is equivalent to the smoke inhaled by active smokers (IARC, 2013). However, the harmful effects of air pollutants go beyond the carcinogenic effects, since exposure to these compounds is associated with cardiovascular, respiratory, metabolic and immune system problems (Kampa \& Castanas 2008). It is estimated that $91 \%$ of the world population lives in regions with polluted air and that 4.2 million people die annually worldwide as a result of exposure to external air pollution (World Health Organization, 2020).

Among the health problems related to air pollution are respiratory and cardiovascular problems (Anderson et al.,

*Corresponding author: Flávio Manoel Rodrigues da Silva Júnior; e-mail: f.m.r.silvajunior@gmail.com 
2012; Kim et al., 2018; Pope et al., 2015; Rabiei et al., 2017), mental disorders (Khan et al., 2019), reduced intellectual capacity (Chen \& Schwartz, 2009; Kilian and Kitazawa, 2018) and the appearance of several types of cancers (IARC, 2013; World Health Organization, 2018). These impairments to the health of the populations are more intense in developing countries, since these countries associate rapid urbanization, accelerated industrial development and intensive use of mineral resources and fossil fuels (Mannucci \& Franchini, 2017).

Despite this critical scenario in developing countries, the number of studies on air quality assessment in these regions is still small (Lindén et al., 2012), and environmental monitoring in these regions is scarce and infrequent (Han \& Naeher, 2006). In Latin America, studies on air pollution are limited to a few cities (Fajersztajn et al., 2017). Furthermore, in Brazil, less than $2 \%$ of all municipalities have an air quality monitoring station and not all air pollutants are monitored at these stations (Réquia et al., 2015).

In 2018, a new legal provision on air quality took effect in Brazil, taking into account the parameters already established by WHO in 2005 (CONAMA, 2018). According to this provision, some of the pollutants that must be monitored are ozone $\left(\mathrm{O}_{3}\right)$, nitrogen dioxide $\left(\mathrm{NO}_{2}\right)$, sulfur dioxide $\left(\mathrm{SO}_{2}\right)$, inhalable particles $\left(\mathrm{PM}_{10}\right.$ and $\left.\mathrm{PM}_{2.5}\right)$ and carbon monoxide (CO).

The region of the present study comprises municipalities with problems related to environmental pollution that have already been widely discussed (da Silva Júnior et al., 2013, 2019; Gutierrez et al., 2020; Tavares et al., 2018). Among the sources of pollution are vehicular traffic and industrial complex (Rio Grande and Pelotas) and mining activities (other cities).
Although these sources of pollution are capable of affecting air quality, the number of studies about atmospheric pollution in this region is very small and limited to concentration levels (Gutierrez et al., 2020) or composition of inhalable particles. The latter being represented by studies that investigated the presence of lead in the airborne PM in the city of Rio Grande (Vanz et al., 2003) and that assessed $\mathrm{NO}_{2}$ levels in the city of Candiota (Dallarosa et al., 2004).

In this sense, the present study aimed to evaluate air quality in nine municipalities in the extreme south of Brazil, based on the monitoring of six pollutants $\left(\mathrm{O}_{3}, \mathrm{NO}_{2}, \mathrm{SO}_{2}\right.$, $\left.\mathrm{PM}_{2.5}, \mathrm{PM}_{10} \mathrm{e} \mathrm{CO}\right)$ and the relationship of these pollutants with meteorological parameters.

\section{MATERIAL AND METHODS}

\section{Study area}

The study area (Figure 1) comprises 9 municipalities located in the extreme south of Brazil, in the State of Rio Grande do Sul. Pelotas (approx. 328 thousand inhabitants), Rio Grande (approx. 197 thousand inhabitants) and Bagé (approx. 117 thousand inhabitants) are the largest cities in the region. The other municipalities have smaller populations: Pinheiro Machado (12,780 inhabitants), Candiota $(8,771$ inhabitants), Herval (6,753 inhabitants), Hulha Negra (6,043 inhabitants), Aceguá (4,394 inhabitants) and Pedras Altas (2,212 inhabitants) (Brasil, 2010). The economy of these municipalities is based on industrial activities, trade and services (Group I - Rio Grande and Pelotas), trade, agriculture

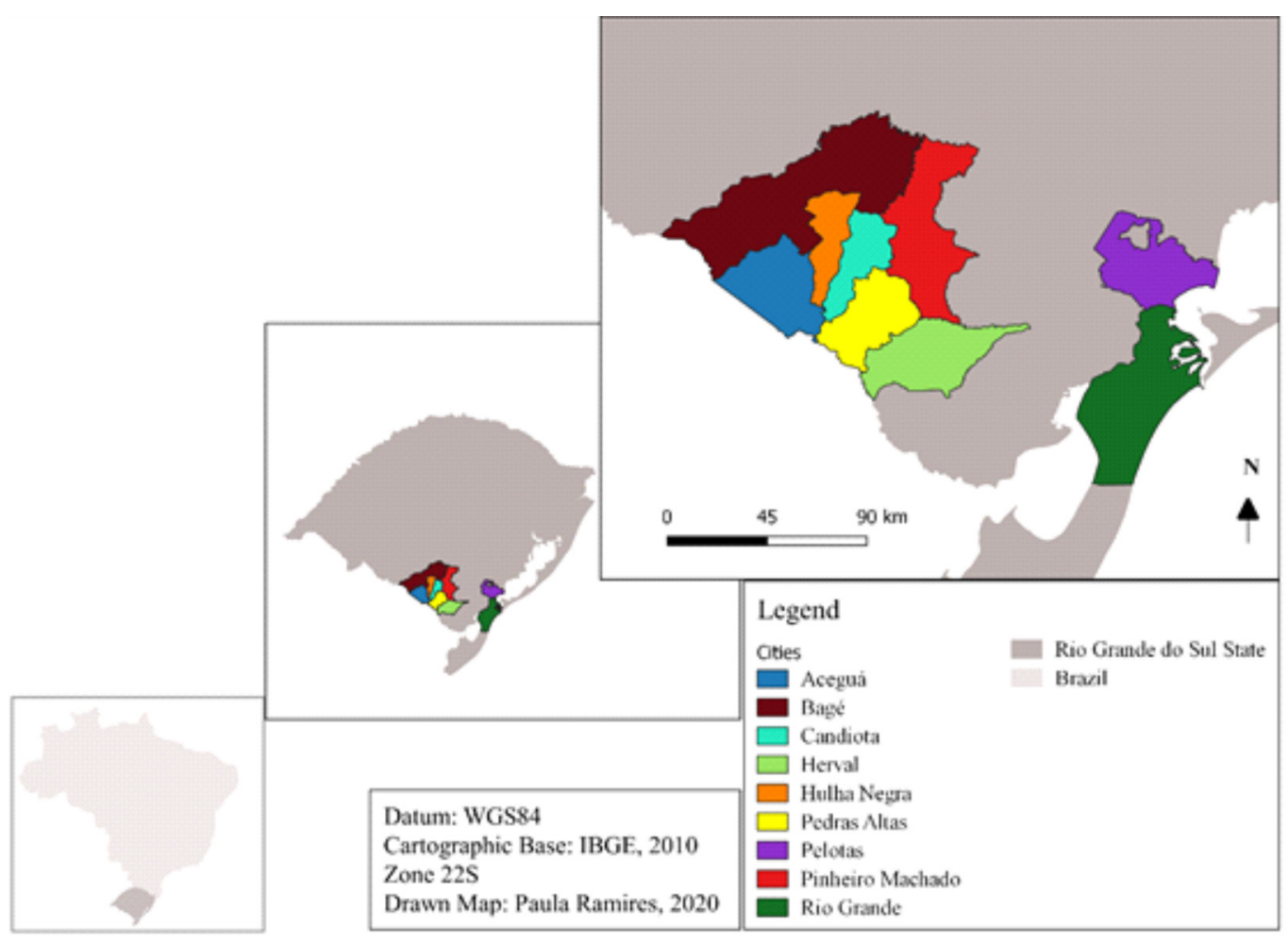

Figure 1. Map of the studied region. 
and livestock (Group II - Bagé), agriculture, livestock and extraction and industrial use of ores (Group III - Candiota, Pinheiro Machado, Pedras Altas, Hulha Negra) and trade, agriculture and livestock (Group IV - Aceguá and Herval).

\section{Data Collection and Analysis}

The concentration levels $\left(\mu \mathrm{g} \mathrm{m}^{-3}\right)$ of air pollutants $\left(\mathrm{O}_{3}\right.$, $\mathrm{NO}_{2}, \mathrm{SO}_{2}, \mathrm{PM}_{2.5}, \mathrm{PM}_{10}$ and $\mathrm{CO}$ ), humidity (\%), atmospheric pressure $(\mathrm{mb})$ and wind speed $(\mathrm{m} / \mathrm{s})$ were collected from satellite data from the European Center for Medium-Range Weather Forecasts (ECMWF) "Copernicus Atmospheric Monitoring Service", extracted daily at $12 \pm 1 \mathrm{pm}$, with the aid of The Wealther Channel (IBM, USA) app.

The data of wind speed and direction, rainfall $(\mathrm{mm})$ and average temperature $\left({ }^{\circ} \mathrm{C}\right)$ were obtained from data available by automatic stations of the National Meteorological Institute (INMET 2020). The analysis period ranged from April 25, 2020 to July 4, 2020. Wind roses were plotted using the WRPLOT View TM software (version 8.0.2), while Pearson's correlation analysis $(\mathrm{p}<0.05)$ and Cluster analysis using the Euclidean distance were performed using the STATISTICA 7.0 software.

\section{RESULTS}

The winds in the region were predominantly of low and medium intensity. The dominant directions in Rio Grande and
Pelotas were WSW and NE, while in Bagé they were N and SW (Figure 2). The average values and the range of pollutants analyzed in each city are summarized in Table 1 . The pollutants $\mathrm{O}_{3}, \mathrm{CO}, \mathrm{PM}_{10}$ and $\mathrm{PM}_{25}$ had higher averages in Rio Grande and Pelotas when compared to the other municipalities, while $\mathrm{NO}_{2}$ and $\mathrm{SO}_{2}$ had higher values in the municipalities of Candiota, Pinheiro Machado and Pedras Altas. The limits set by CONAMA in Resolution 491/2018 were exceeded only once during the analyzed period $\left(\mathrm{PM}_{2.5}\right.$ in Rio Grande) (data not shown). In general, the pollutants' temporal behavior was similar between Rio Grande and Pelotas and also showed some similarity when analyzing the temporal profile of the other seven municipalities (Figure 3, a-i). The Cluster analysis grouped the following municipalities by similarity: Cluster 1, Rio Grande and Pelotas; Cluster 2, Bagé and Hulha Negra; Cluster 3, Aceguá and Herval; and Cluster 4, Candiota, Pedras Altas and Pinheiro Machado (Figure 4), with the exception of Cluster II, the construction of Clusters was related to the predominant type of economic activities (represented by Groups I, II, III and IV).

The correlations between Atmospheric Pollutants and Meteorological Parameters are shown in Table 2. Wind speed had a significant weak negative correlation with all pollutants, except for $\mathrm{O}_{3}$, where the correlation was positive (weak). The temperature showed a significant positive correlation with all pollutants (with the exception of $\mathrm{SO}_{2}$ ). Atmospheric pressure had a negative correlation with $\mathrm{NO}_{2}$ and $\mathrm{CO}$ and a weak positive correlation with $\mathrm{O}_{3} \cdot \mathrm{O}_{3}$ also had a negative

Table 1. Average concentrations (minimum - maximum) of air pollutants in $\boldsymbol{\mu g ~ m}^{-3}$ in cities of the extreme south of Brazil.

\begin{tabular}{lcccccc}
\hline City & $\mathbf{O}_{3}$ & $\mathbf{N O}_{2}$ & $\mathbf{S O}_{2}$ & $\mathbf{P M}_{2.5}$ & $\mathbf{P M}_{10}$ & $\mathbf{C O}$ \\
\hline Rio Grande & $56.64(36.95-89.0)$ & $1.32(1-3.12)$ & $1.32(1-4.22)$ & $5.05(0.98-33.37)$ & $8.3(1.75-47.73)$ & $117.9(100-248.2)$ \\
Pelotas & $52.73(34.8-80.32)$ & $1.44(1-3.51)$ & $1.28(1-3.28)$ & $4.46(1.02-23.53)$ & $6.89(1.5-33.73)$ & $119.7(100-250.8)$ \\
Bagé & $47.93(24.9-78.6)$ & $1.39(1-3.44)$ & $1.49(1-5.44)$ & $3.65(1.06-14.72)$ & $5.37(1.56-21.23)$ & $116.4(100-180.3)$ \\
Candiota & $46.52(26.7-74.9)$ & $2.37(1-6.58)$ & $5.18(2.1-10.8)$ & $3.54(0.88-12.81)$ & $5.31(1.28-18.71)$ & $115.7(100-175)$ \\
Pedras Altas & $46.16(25.9-74.02)$ & $2.42(1-7.66)$ & $5.64(1-14.44)$ & $3.51(0.86-12.19)$ & $5.3(1.28-18.13)$ & $114.7(100-172.1)$ \\
Hulha Negra & $47.64(27.7-77.92)$ & $1.68(1-4.15)$ & $2.50(1-7.36)$ & $3.58(0.99-13.91)$ & $5.33(1.45-20.16)$ & $115.7(100-178.3)$ \\
Pinheiro Machado & $46.55(28.6-78.37)$ & $2.39(1-6.28)$ & $5.47(2.27-13.41)$ & $3.69(0.72-12.82)$ & $5.55(1.05-18.36)$ & $115.8(100-193.8)$ \\
Herval & $47.97(26.4-77.8)$ & $1.34(1-3.53)$ & $1.65(1-6.39)$ & $3.39(0.63-11.93)$ & $5.19(1-18.58)$ & $113.4(100-183.5)$ \\
Aceguá & $47.65(22.8-73.64)$ & $1.18(1-2.59)$ & $1.29(1-3.88)$ & $3.33(0.7-11.71)$ & $5.01(1.12-17.36)$ & $114.2(100-172.6)$ \\
\hline
\end{tabular}
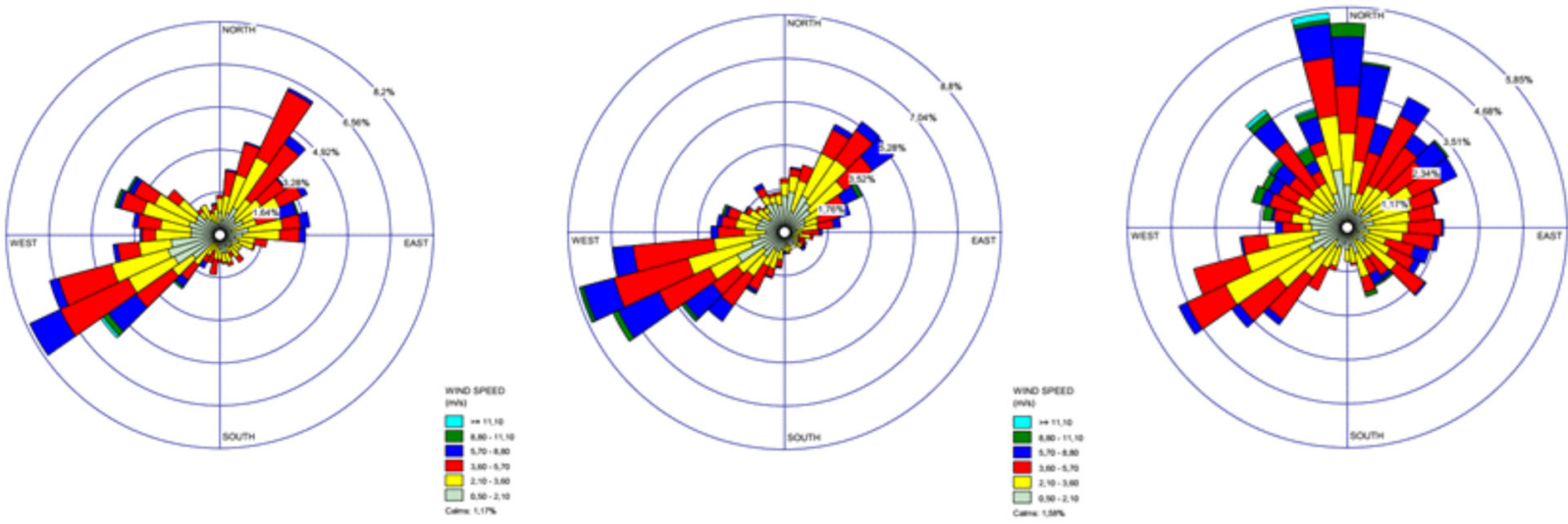

Figure 2. Wind roses in the cities of Rio Grande, Pelotas and Bagé, RS, Brazil. 

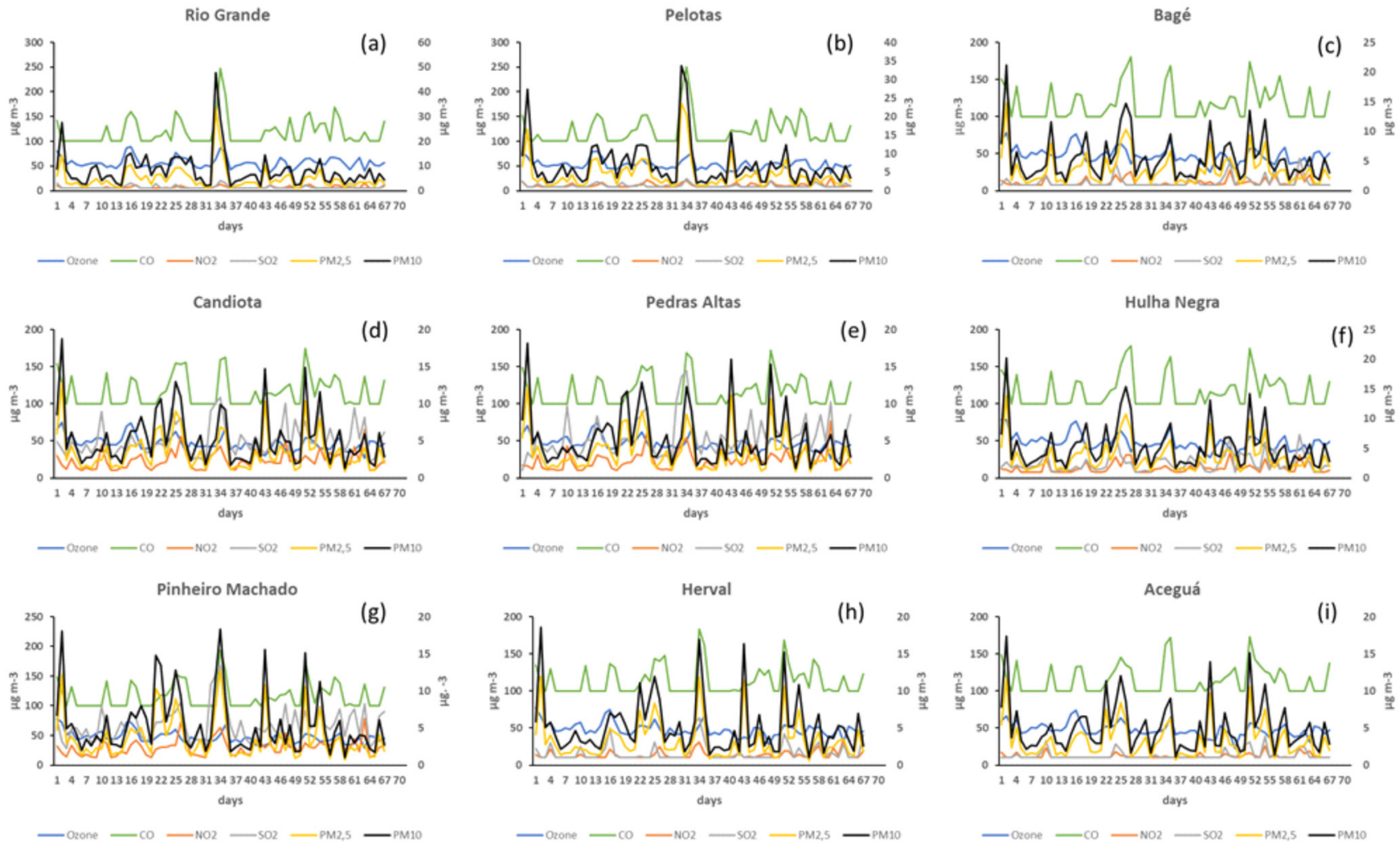

Figure 3. Temporal variation of air pollutants in the cities studied (a) Rio Grande; (b) Pelotas; (c) Bagé; (d) Candiota; (e) Pedras Altas; (f) Hulha Negra; (g) Pinheiro Machado; (h) Herval and (i) Aceguá. Principal y-axis: ozone and CO; Secondary y-axis: $\mathrm{NO}_{2}, \mathrm{SO}_{2}, \mathrm{PM}_{2.5}$ and $\mathrm{PM}_{10 .}$

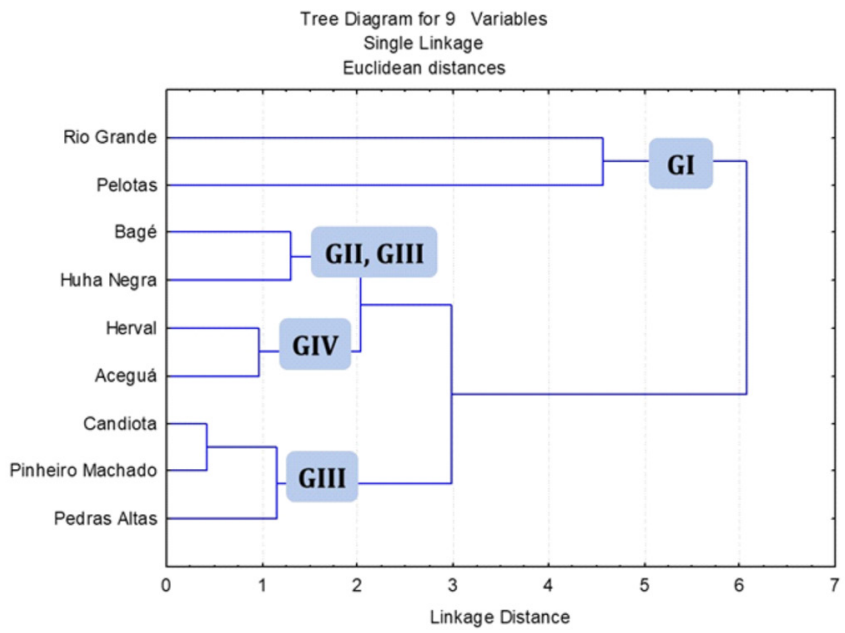

Figure 4. Cluster analysis of the municipalities studied using air pollutant concentration data. GI, GII, GIII and GIV refer to groups of municipalities based on the set of predominant economic activities.

correlation with humidity and rainfall, while $\mathrm{NO}_{2}$ had a positive correlation with humidity.

\section{DISCUSSION}

The present study revealed that the evaluated air pollutants were in compliance with the Brazilian standards during the investigated period, with the exception of a single episode, in which $\mathrm{PM}_{25}$ exceeded the limit of $25 \mu \mathrm{g} \mathrm{m}^{-3}$ established by CONAMA Resolution 491/2018 (CONAMA, 2018). The municipalities that compose the extreme south of Brazil are sites of interest in the area of environmental health, since they have several potential polluting activities, such as the exploration and use of mineral coal and other ores (Secretaria de Planejamento, Orçamento e Gestão do Rio Grande do Sul, 2019), industrial complexes and port activities (Secretaria de Planejamento, Mobilidade e Desenvolvimento Regional, 2015). In addition, the human development index of these cities is lower than that of others in the State of Rio Grande do Sul. The social and economic vulnerability of the region has already been reported in other studies (Ferreira \& Pinto, 2017; Salati de Souza \& Avila Martins, 2016).

The few studies on air pollution in the study region report past and occasional scenarios. Dallarosa et al. (2007) studying the application of numerical models for the formation of $\mathrm{O}_{3}$ in the city of Candiota showed relatively low levels of $\mathrm{NO}_{2}$ during the summer of 2003 and the winter of 2004. The studies by Lemos et al. (2012) and Gutierrez et al. (2020) investigated the $\mathrm{PM}_{2.5}$ levels at two sites in the city of Rio Grande, an urban and an urban-industrial area with sampling during the period from October 2009 to January 2010 and October 2009 to May 2011, respectively. The study by Lemos et al. (2012), as it was during a shorter period, found only two values of $\mathrm{PM}_{25}$ above the limit of $25 \mu \mathrm{g} \mathrm{m}^{3}$. On the other hand, in the study by Gutierrez et al (2020) more than $50 \%$ of the samples were above the CONAMA resolution limits. 
Table 2. Correlations between meteorological parameters and air pollutants.

\begin{tabular}{|c|c|c|c|c|c|c|}
\hline Parameter & $\mathrm{O}_{3}$ & $\mathrm{NO}_{2}$ & $\mathrm{SO}_{2}$ & $\mathbf{P M}_{2.5}$ & $\mathbf{P M}_{10}$ & $\mathrm{CO}$ \\
\hline Humidity (\%) & $\begin{array}{c}-0.41 \\
(<0.001)\end{array}$ & $\begin{array}{c}0.19 \\
(<0.001)\end{array}$ & ns & ns & ns & ns \\
\hline Pressure $(\mathrm{mb})$ & $\begin{array}{c}0.09 \\
(0.02)\end{array}$ & $\begin{array}{c}-0.25 \\
(<0.001)\end{array}$ & ns & ns & ns & $\begin{array}{c}-0.32 \\
(<0.001)\end{array}$ \\
\hline Wind Speed $\left(\mathrm{m} \mathrm{s}^{-1}\right)$ & $\begin{array}{c}0.1 \\
(0.01)\end{array}$ & $\begin{array}{c}-0.22 \\
(<0.001)\end{array}$ & $\begin{array}{c}-0.15 \\
(<0.001)\end{array}$ & $\begin{array}{c}-0.12 \\
(0.004)\end{array}$ & $\begin{array}{l}-0.08 \\
(0.04)\end{array}$ & $\begin{array}{l}-0.12 \\
(0.002)\end{array}$ \\
\hline Temperature $\left({ }^{\circ} \mathrm{C}\right)$ & $\begin{array}{c}0.36 \\
(<0.001)\end{array}$ & $\begin{array}{c}0.20 \\
(<0.001)\end{array}$ & ns & $\begin{array}{c}0.36 \\
(<0.001)\end{array}$ & $\begin{array}{c}0.36 \\
(<0.001)\end{array}$ & $\begin{array}{c}0.52 \\
(<0.001)\end{array}$ \\
\hline Rainfall (mm) & $\begin{array}{c}-0.24 \\
(<0.001)\end{array}$ & ns & $\begin{array}{l}-0.12 \\
(0.004)\end{array}$ & ns & ns & ns \\
\hline
\end{tabular}

As reported by Gutierrez et al (2020), temperature had a positive correlation with $\mathrm{PM}_{2.5}$. In fact, temperature was the most prominent meteorological parameter in relation to its association with air pollutants (except for $\mathrm{SO}_{2}$ ). In this context, the correlation with pollutants was above $r>0.25$ for $\mathrm{O}_{3}, \mathrm{PM}_{10}, \mathrm{PM}_{2.5}$ and $\mathrm{CO}$. On the other hand, wind speed was significantly associated with all pollutants and, with the exception of $\mathrm{O}_{3}$, although weak $(|\mathrm{r}|<0.25)$ it was always negative. The association between increased pollutants and atmospheric stability has been reported in other studies (Lindén et al., 2012).

The association between meteorological parameters and air pollutants is well known in the literature (Hrishikesh \& Nagendra, 2019; Moura et al., 2020). However, the peculiarities of this relationship are dependent, among other factors, on the location studied and on the data sampling time. In this sense, the present study is pioneer in reporting the influence of meteorological parameters on air pollutants in this region.

Among the air pollutants investigated, $\mathrm{O}_{3}$ was significantly correlated with all parameters evaluated, a response similar to that found in other studies (De Souza et al. 2016, Jasaitis et al. 2016). For other pollutants, such as $\mathrm{PM}_{2.5}$ and $\mathrm{PM}_{10}$, the speed of the winds seems to have a contribution in reducing their local levels (Nogarotto \& Pozza 2020), as verified in the present study.

In this study region, the economic activity in each municipality strongly influenced the concentration profile of air pollutants. Clusters between municipalities were established primarily by the types of economic activity prevalent in the municipality, to the detriment of other factors, such as geographical location, geographical proximity or population size.

Despite bringing extremely relevant data, the present study has among its limitations the method of data acquisition. The recording of data through real-time satellite information limits the comparison with the permissive values provided by the CONAMA resolution, as they differ from methodologies for analyzing pollutants (CONAMA, 2018). Even so, the use of these tools is extremely important as they allow comparisons between different locations, as well as the real-time monitoring of data. The strategy of using satellite data obtained through websites or mobile applications has been widely used (Deshmukh et al., 2020; Hrishikesh \& Nagendra, 2019; John Joseph, 2019; Muñoz \& Pizarro, 2019). In addition, its use was intensified during the COVID-19 Pandemic as a way of drawing a panorama and performing comparisons more quickly (Li et al., 2020). Moreover, many studies have sought to validate the use of these tools. The study by Bickel \& Kim (2008) reported that The Wealther Channel (IBM, USA) is a reliable tool for studies with real-time data acquisition or in short-term forecasts. These same findings were described by Bumbary (2018), who also points out that these tools can be extremely useful in developing countries, due to the high costs of installing equipment to monitor weather and air pollutants.

Although the study brings extremely useful results due to its originality, we point out some limitations. The first is that even though the investigation period was over 60 days, data collection occurred in an atypical year with profound changes in urban mobility and reduction of activities, due to the COVID-19 Pandemic. The normally low concentrations of the pollutants may be related to the measures used to control mobility and social distance and we suggest longterm monitoring for a complete investigation scenario. The other limitation is that the database was obtained from data collection in a single period of the day. It is known that pollutant concentrations are variable throughout the day and future studies should contemplate an analysis of the daily behavior of pollutants.

\section{CONCLUSION}

The study showed that the air pollutants analyzed $\left(\mathrm{O}_{3}, \mathrm{NO}_{2}, \mathrm{SO}_{2}, \mathrm{PM}_{2.5}, \mathrm{PM}_{10}\right.$ e $\left.\mathrm{CO}\right)$ were within the levels acceptable by current legislation, during the sampling period. Meteorological parameters, such as humidity, atmospheric pressure, rainfall, temperature and wind speed, have, to a greater or lesser extent, influence on air pollutants. In addition to them, the composition of air pollutants in each municipality is dependent on its local economic activity. We encourage the continuity of studies in the region aiming at a complete temporal analysis that encompasses all seasons. 


\section{FUNDING}

This study was financed in part by the Coordenação de Aperfeiçoamento de Pessoal de Nível Superior - Brasil (CAPES) - Finance Code 001.

\section{REFERENCES}

ANDERSON, J.O., THUNDIYIL, J.G. \& STOLBACH, A. 2012 Clearing the Air: A Review of the Effects of Particulate Matter Air Pollution on Human Health. J. Med. Tox., 136(12): 48674881. http://dx.doi.org/10.1007/s13181-011-0203-1

BICKEL, J.E. \& KIM, S.D. 2008. Verification of the weather channel probability of precipitation forecasts. Mon. WeatherVer., 136(12), 4867-4881. http://dx.doi.org/10.1175/2008MWR2547.1

BRASIL, INSTITUTO BRASILEIRO DE GEOGRAFIA E ESTATÍSTICA - IBGE. 2010. Pesquisa Nacional de Saneamento Básico - PNSB 2008. Ministério das cidades.

BUMBARY, T.M. 2017. Utilizing a network of wireless weather stations to forecast weather in developing countries. In 2017 IEEE Integrated STEM Education Conference (ISEC): 109-111. http://dx.doi.org/10.1109/ISECon.2017.7910223

CHEN, J.C. \& SCHWARTZ, J. 2009. Neurobehavioral effects of ambient air pollution on cognitive performance in US adults. Neurotoxicol., 30(2): 231-239. http://dx.doi.org/10.1016/j. neuro.2008.12.011.

CONAMA. 2018. Resolução n 491/18 de 18 de novembro de 2018.: 7. Available at: http://www2.mma.gov.br/port/conama/legiabre. cfm?codlegi $=740$.

DA SILVA JÚNIOR, F.M.R., SILVA, P.F., GARCIA, E.M., KLEIN, R.D., PERAZA-CARDOSO, G., BAISCH, P.R., VARGAS, V.M.F., MUCCILLO-BAISCH, A.L. 2013. Toxic effects of the ingestion of water-soluble elements found in soil under the atmospheric influence of an industrial complex. Environ. Geochem. Health, 35(3): 317-331. http://dx.doi.org/10.1007/ s10653-012-9496-5.

DA SILVA JÚNIOR, F.M.R, RAMIRES, P.F., DOS SANTOS, M. SEUS, E.R., SOARES, M.C.F., MUCCILLO-BAISCH, A.L., BAISCH, P.R.M. 2019. Distribution of potentially harmful elements in soils around a large coal-fired power plant. Environ. Geochem. Health, 41(5): 2131-2143. http://dx.doi.org/10.1007/ s10653-019-00267-w.

DAllarosA, J.B., TEIXEIRA, E.C, PIRES, M. 2004. Estudos de hidrocarbonetos policíclicos aromáticos em aerossóis atmosféricos na região de Candiota, RS. In: Estudo Ambientais Em Candiota Carvão e Seus Impactos. Porto Alegre, pp. 89-96.

DE SOUZA, A., KOVAČ-ANDRIĆ, E., MATASOVIĆ, B. \& MARKOVIĆ, B. 2016. Assessment of ozone variations and meteorological influences in west Center of Brazil, from 2004 to 2010. Water Air Soil Poll., 227(9), 313. http://dx.doi. org/10.1007/s11270-016-3002-0

DESHMUKH, P., KIMBROUGH, S., KRABBE, S., LOGAN, R., ISAKOV, V., BALDAUF, R. 2020. Identifying air pollution source impacts in urban communities using mobile monitoring. Sci. Total Environ., 715: 136979. http://dx.doi.org/10.1016/j. scitotenv.2020.136979.

FAJERSZTAJN, L., SALDIVA, P., PEREIRA, L.A.A., LEITE, V.F., BUEHLER, A.M. 2017. Short-term effects of fine particulate matter pollution on daily health events in Latin America: a systematic review and meta-analysis. Int. J. Public Health, 62(7): 729-738. http://dx.doi.org/10.1007/s00038-017-0960-y.

FERREIRA, G.S. \& PINTO, C.V.S. 2017. Desenvolvimento humano, vulnerabilidade e prospectiva social no Rio Grande do
Sul: uma visão inter e intrarregional por meio dos COREDES. In: Marguti, B.O., Costa, M.A., \& Pinto, C.V.S. (eds), Territórios Em Números: Insumos Para Políticas Públicas a Partir Da Análise Do IDHM e Do IVS de Municípios e Unidades Da Federação Brasileiro. Brasilia: IPEA, p. 245.

GUTIERREZ, F.B., MARTINS, S.E., HONSCHA, L.C., BRUM, R.L., VARGAS, V.M.F., MIRLEAN, N., BAISCH, P.R.M., DA SILVA-JÚNIOR, F.M.R. 2020. Is There Something in the Air? Sources, Concentrations and Ionic Composition of Particulate Matter (PM2.5) in an Industrial Coastal City in Southern Brazil. Water Air Soil Poll., 31(5). http://dx.doi.org/10.1007/s11270020-04611-0.

HAN, X. \& NAEHER, L.P. 2006. A review of traffic-related air pollution exposure assessment studies in the developing world. Environ. Int., 32: 106-20. http://dx.doi.org/10.1016/j. envint.2005.05.020.

HRISHIKESH, C.G. \& NAGENDRA, S.M.S. 2019. Study of meteorological impact on air quality in a humid tropical urban area. J. Earth Syst. Sci., 128(5): 1-18. http://dx.doi.org/10.1007/ s12040-019-1116-7.

IARC. 2013. Outdoor air pollution a leading environmental cause of cancer deaths. International Agency for Research on Cancer.

JASAITIS, D., VASILIAUSKIENĖ, V., CHADYŠIENĖ, R. \& PEČIULIENĖ, M. 2016. Surface ozone concentration and its relationship with UV radiation, meteorological parameters and radon on the eastern coast of the Baltic Sea. Atmosphere, 7(2), 27. http://dx.doi.org/10.3390/atmos7020027

JOHN JOSEPH, F.J. 2019. Empirical Dominance of Features for Predictive Analytics of Particulate Matter Pollution in Thailand. 5th Thai-Nichi Institute of Technology Academic Conference, TNIAC 2019: 385-388.

KAMPA, M. \& CASTANAS, E. 2008. Human health effects of air pollution. Environ. Pollut., 151(2): 362-367. http://dx.doi. org/10.1016/j.envpol.2007.06.012

KHAN, A., PLANA-RIPOLL, O., ANTONSEN, S., BRANDT, J., GEELS, C., LANDECKER, H., SULLIVAN, P.F., PEDERSEN, C.B., RZHETSKY, A. 2019. Environmental pollution is associated with increased risk of psychiatric disorders in the US and Denmark. PLoS Biol., 17(8): e3000353. http://dx.doi. org/10.1371/journal.pbio.3000353.

KILIAN, J. \& KITAZAWA, M. 2018. The emerging risk of exposure to air pollution on cognitive decline and Alzheimer's disease Evidence from epidemiological and animal studies. Biomed. J., 41(3): 141-162. http://dx.doi.org/10.1016/j.bj.2018.06.001.

KIM, D., CHEN, Z., ZHOU, L.F. \& HUANG, S.X.. 2018. Air pollutants and early origins of respiratory diseases. Chronic Dis. Transl. Med., 4(2): 75-94. http://dx.doi.org/10.1016/j. cdtm.2018.03.003.

LEMOS, A.T., CORONAS, M.V., ROCHA, J.A.V., VARGAS, V.M.F. 2012. Mutagenicity of particulate matter fractions in areas under the impacts of urban and industrial activities. Chemosphere 89 (9): 1126-1134. http://dx.doi.org/10.1016/j. chemosphere.2012.05.100

LI, H., XU, X.L., DAI, D.W., HUANG, Z.Y., MA, Z., GUAN, Y.J. 2020. Air Pollution and temperature are associated with increased COVID-19 incidence: a time series study. Int. J. Infect. Dis., 97: 278-282. http://dx.doi.org/10.1016/j.ijid.2020.05.076.

LINDÉN, J., BOMAN, J., HOLMER, B.,THORSSON, S., ELIASSON, I. 2012. Intra-urban air pollution in a rapidly growing Sahelian city. Environ. Int., 40: 51-62. http://dx.doi. org/10.1016/j.envint.2011.11.005.

MANNUCCI, P.M. \& FRANCHINI, M. 2017. Health effects of ambient air pollution in developing countries. Int. J. Environ. Res. Public Health, 14: 1048. http://dx.doi.org/10.3390/ 
ijerph14091048.

MOURA, P.H., WILliAM, D., SANTOS, L., MORENO, A.M., SOBREIRA, P.G.P., SILVA, F.P., MAIA, L.F.P.G. 2020. Análise da qualidade do ar e fatores meteorológicos na cidade de Nova Iguaçu (Rio de Janeiro - Brasil) entre os anos de 2000 a 2016. Ver. Bras. Meio Ambiente, 8(1): 87-99. http://dx.doi. org/10.5281/zenodo.3633889

MUÑOZ, L.A. \& PIZARRO, D.A. 2019. Environmental monitoring and warning system at strategic points in the city. In: 2019 IEEE Chilean Conference on Electrical, Electronics Engineering, Information and Communication Technologies (CHILECON2019), pp. 1-6.

NOGAROTTO, D.C. \& POZZA, S.A. 2020. A review of multivariate analysis: is there a relationship between airborne particulate matter and meteorological variables?. Environ. Monit. Assess., 192(9), 1-14. http://dx.doi.org/10.1007/s10661020-08538-1

POPE, C.A., TURNER, M.C., BURNETT, R.T., JERRETT, M., GAPSTUR, S.M., DIVER, W.R., KREWSKI, D., BROOK, R.D. 2015. Relationships between fine particulate air pollution, cardiometabolic disorders, and cardiovascular mortality. Circ. Res., 116(1): 108-15. http://dx.doi.org/10.1161/ circresaha.116.305060

RABIEI, K., HOSSEINI, S.M., SADEGHI, E., JAFARI-KOSHKI, T., RAHIMI, M., SHISHEHFOROUSH, M., LAHIJANZADEH, A., SADEGHIAN, B., MOAZAM, E., MOHEBI, M.B., EZATIAN, V., SARRAFZADEGAN, N. 2017. Air pollution and cardiovascular and respiratory disease: Rationale and methodology of CAPACITY study. ARYA Ather, 13(6): 264273. http://dx.doi.org/10.22122/arya.v13i6.1614

RÉQUIA, W.J., KOUTRAKIS, P. \& ROIG, H.L. 2015. Spatial distribution of vehicle emission inventories in the Federal
District, Brazil. Atmos. Environ., 112: 32-39. http://dx.doi. org/10.1016/j.atmosenv.2015.04.029

SALATI DE SOUZA, P.R. \& AVILA MARTINS, C.A. 2016. Áreas urbanas desfavorecidas do município do Rio GrandeRS. Geosul, 31(62): 221. http://dx.doi.org/10.5007/2177$5230.2016 \mathrm{v} 31 \mathrm{n} 62 \mathrm{p} 221$

Secretaria de Planejamento, Mobilidade e Desenvolvimento Regional. 2015. Perfil socioeconômico COREDE Sul. Porto Alegre: SPMDR, 2015. 52p.

Secretaria de Planejamento, Orçamento e Gestão do Rio Grande do Sul. 2019. Departamento de Planejamento Governamental; Atlas Socioeconômico do Rio Grande do Sul. Porto Alegre, 2019. $4^{\circ}$ ed. 125p. https://atlassocioeconomico.rs.gov.br/ocorrenciasminerais (accessed 12 July 2020).

TAVARES, C.B.B., HOSCHA, L.C., TAVELLA, R.A., FERNANDES, C.L.F., FANTON, T., BAISCH, P.R.M., CHAVES, I.S., DA SILVA-JÚNIOR, F.M.R. 2018. Rapid tests for the toxicity evaluation of soil contaminated by leadacid batteries manufacture. Ecotox. Environ. Contam., 13(2): 11-17. http://dx.doi.org/10.5132/eec.2018.02.03

VANZ, A., MIRLEAN, N. \& BAISCH, P. 2003. Avaliação de poluição do ar por chumbo particulado: Uma abordagem geoquímica. Quimica Nova, 26(1): 25-29. http://dx.doi. org/10.1590/s0100-40422003000100006

WORLD HEALTH ORGANIZATION. 2018. How air pollution is destroying our health. Available at: https://www.who.int/ airpollution/news-and-events/how-air-pollution-is-destroyingour-health.

WORLD HEALTH ORGANIZATION. 2020. Coronavirus disease (COVID-19) - events as they happen. 2020. Available at: https:// wwwwhoint/emergencies/diseases/novel-coronavirus-2019/ events-as-theyhappen. 